\title{
EDITORIAL COMMENT
}

\author{
MANLEY HODSON \\ 1886-1960
}

Manley Hudson died on April 13, 1960. The statement of his achievements and the principal events in his career are adequately stated in the Proceedings of the Fifty-Fourth Meeting of the American Society of International Law. This is merely a note of appreciative recollection from one of his friends and former colleagues in various enterprises.

It was the vigor of his personality as well as the quality of his mind which made it possible for Manley Hudson to make such an impact upon the development of international law in his time and upon the international lawyers of these last four decades. Nowhere did this combination of qualities appear to greater advantage or with more striking effect than in the work of the Harvard Research in International Law. This notable enterprise, which made contributions of enduring value, was Manley Hudson's in conception, in creation, in management and in results. It was organized by him at the Harvard Law School with a view to assisting or supplementing the work of the League of Nations Preparatory Committee for the International Codification Conference following upon the work of the Committee of Experts for the Progressive Codification of International Law which was set up in 1924. The American Law Institute supplied the model for the type of operation-the black-letter text with commentary. Manley Hudson secured the financial support, organized the Advisory Committee, enlisted the reporters, chaired the meetings, and from beginning to end inspired and drove his colleagues to the production of the best that was in them. His was a technique at which some sensitive souls quailed, for it was his greatest joy to cross intellectual swords with an antagonist in order that the sparks of creative thought could flash across the green baize table.

Those who worked with him will readily recall the delighted smile with which he would welcome a sudden exposition of a defect in a position which he had taken or which he had approved. There was never anything somber about meetings of this kind; there was always in reserve a gaiety and there was good humor and, between the formal sessions, good talk and good fellowship.

The volumes of the Harvard Research are, of course, only a few of the monuments which stand to remind us of Manley Hudson's contributions to international law. This writer mentions them particularly because he had the privilege of being associated with that effort from its beginning to its end and partly because Hudson's name is not always identified with these volumes. Some seem to think of Judge Hudson as if he were merely a compiler because he did edit the nine volumes of International Legisla- 
tion; and he did edit the World Court Reports. Personally this writer envies the achievement indicated by these volumes also with their extraordinarily useful and meticulously prepared notes, guiding one, as no other source does, to surrounding materials of importance in interpreting either a treaty or a judgment or opinion of the Court. His annual articles in the American Journal of International Law on the work of the Court are the studies of a jurist who was a master of the Court's law and procedure and who rendered a great service by following every development with the utmost eare and with ready criticism when criticism was due. His magisterial treatise on the Court in its second edition consolidated and amplified his analysis down through 1942.

It is, of course, true that Judge Hudson never wrote a comprehensive treatise on international law, but a mere glance at the analytical index of the American Journal of International Law and of the Proceedings of the Society covering the years 1921 to 1940 will show the breadth of his contributions to all subjects of international law, particularly through the editorials which he wrote and through his participation in the discussions at the annual meetings.

No attempt is made to record here all of his contributions, either those made in writing or those made by him in person, as through his service as a Judge on the bench of the Court or as a member of the International Law Commission, or as an international civil servant, or as a citizen or as a teacher. Those of us who were privileged to work with Manley Hudson, of course, are conscious of our loss, realizing the stimulus which has gone from among us. It would be our hope that some who did not come under his spell may now realize the extent of the loss that they too have suffered.

Philip C. Jessup 